\title{
The work of a Brazilian nursing team of collective health in the special indigenous health district
}

\author{
O trabalho em saúde coletiva da equipe de enfermagem brasileira no distrito sanitário especial indígena \\ El trabajo de salud colectiva del equipo de enfermería brasileña en el distrito sanitario especial indígena
}

'Universidade Estadual de Roraima. Boa Vista, Roraima, Brazil.

"Universidade Guarulhos. Guarulhos, São Paulo, Brazil.

II' Pesquisador independente. São Paulo, São Paulo, Brazil.

\author{
ORCID: 0000-0003-2061-8433 \\ Noélle de Oliveira Freitas" \\ ORCID: 0000-0001-6742-5247 \\ Maíra Rosa Apostolico"' \\ ORCID: 0000-0003-2578-8685
}

Jair da Silva Melo'

How to cite this article: Melo JS, Freitas NO, Apostolico MR. The work of a Brazilian nursing team of collective health in the special indigenous

health district. Rev Bras Enferm. 2021;74(2):e20200116. https://doi.org/10.1590/0034-7167-2020-0116

\section{Corresponding author: \\ Maíra Rosa Apostolico maira.apostolico@gmail.com}

EDITOR IN CHIEF: Antonio José de Almeida Filho ASSOCIATE EDITOR: Álvaro Sousa

Submission: $07-15-2020$

Approval: $10-14-2020$

\section{ABSTRACT}

Objective: To identify the potential and the limits of the actions of the nursing team in the Primary Health Care for the Health of the Indigenous. Methods: This is a quantitative study guided by the Theory of Practical Intervention of Nursing and Collective Health. 230 nursing professionals participated, responding to an instrument about the frequency of the actions carried out in assistance, management, teaching, and research. Results: 168 nursing technicians and 62 nurses participated. As strengths, $80 \%$ participated in the assistance most of the time. Stand out: $90.3 \%$ and $71 \%$ of nurses carried out nursing consultations and house visits, respectively. As a limitation, the involvement in education and research is small. Only $2 \%$ of the interviewees carried out scientific researches, reflecting the need to broaden and qualify care and improve the use of traditional practices, overcoming the biomedical model. Final considerations: Nursing assistance is essential in the modification and monitoring of the epidemiological profile of indigenous populations, and its results allow for the planning of quality actions.

Descriptors: Nursing; Nursing, Team; Public Health; Health of Indigenous Peoples, Indigenous Population.

\section{RESUMO}

Objetivo: Identificar potencialidades e limites da atuação da equipe de enfermagem na Atenção Primária em Saúde Indígena. Métodos: Estudo de abordagem quantitativa orientado pela Teoria da Intervenção Práxica da Enfermagem em Saúde Coletiva. Participaram 230 profissionais de enfermagem, respondendo um instrumento sobre a frequência das ações realizadas na assistência, gestão, ensino e pesquisa. Resultados: Foram 168 técnicos de enfermagem e 62 enfermeiros. Como potencialidades, $80 \%$ participam da assistência na maior parte do tempo. Destacam-se: consulta de enfermagem e visita domiciliária realizada por $90,3 \%$ e $71 \%$ dos enfermeiros, respectivamente. Como limite, o envolvimento na educação e pesquisa é pequeno: apenas $2 \%$ dos entrevistados realizaram pesquisa científica, refletindo a necessidade de ampliar e qualificar o cuidado e aprimorar o uso das práticas tradicionais, superando o modelo biomédico. Considerações finais: A assistência de enfermagem é essencial na modificação e monitoramento dos perfis epidemiológicos da população indígena, e os resultados permitem o planejamento de ações qualificadas.

Descritores: Enfermagem; Equipe de Enfermagem; Saúde Coletiva; Saúde de Populações Indígenas; População Indígena.

\section{RESUMEN}

Objetivo: Identificar potencialidades y límites de actuación del equipo de enfermería en Atención Primaria de Salud Indígena. Métodos: Estudio de abordaje cuantitativo orientado por la Teoría de la Intervención Práxica de Enfermería en Salud Colectiva. Participaron 230 profesionales de enfermería, respondiendo instrumento sobre la frecuencia de acciones realizadas en asistencia, gestión, enseñanza e investigación. Resultados: Como potencialidades, $80 \%$ participan de la asistencia en la mayor parte del tiempo. Destacan: consulta de enfermería y visita domiciliaria realizada por $90,3 \%$ y $71 \%$ de los enfermeros. Como límite, el envolvimiento en la educación e investigación: solo $2 \%$ de los entrevistados realizaron investigación científica, reflejando la necesidad de ampliar y calificar el cuidado y perfeccionar el uso de prácticas tradicionales, superando el modelo biomédico. Consideraciones finales: La asistencia de enfermería es esencial en la modificación y monitoreo de los perfiles epidemiológicos de la población indígena, y los resultados permiten el planeamiento de acciones cualificadas. Descriptores: Enfermería; Equipo de Enfermería; Salud Colectiva; Salud de Poblaciones Indígenas; Población Indígena. 


\section{INTRODUCTION}

From the perspective of collective health and considering the context of the Single Health System (SUS), health actions extrapolate institutional spaces, mainly reaching other territories of professional action. This results from the transformations originated from state interventions in health and in the diseases of the population, which has been noticed in the last years.

Nursing went from a vocational practice to a social one, with the development of its technical-scientific and ethical content. The characteristic heterogeneity of nursing practices, be it due to the multiplicity of actions, to the different insertions in health services, or due to the composition of the nursing and health team, imposed the need to explore and identify the contradictions that involve the entire process of production of health ${ }^{(1)}$.

It is necessary to consider that the economic, political, social, and technological changes, through time, led to new ways to organize work, in addition to new demands and attributions for professionals. Since Brazil is a geographically large country with diverse social and cultural practices, one must consider the need of getting to know all spaces and their particularities. In addition to being large, the country also has a sizable population, with much ethnic and cultural diversity. Considering this multiplicity, the attention to the indigenous peoples of Brazil is an example of how different systems and models of health care coexist.

After numerous changes in the political and managerial model of Indigenous Primary Health Care (IPHC), and attending to the directives of the National Policy for the Health Care of Indigenous Peoples (PNAISP) ${ }^{(2)}$, the Special Secretariat for the Health of the Indigenous (SESAI) was created in 2010, being responsible, exclusively, for the management and execution of health programs and actions, with a robust administrative structure. After the PNASPI was created, indigenous peoples started to be assisted integrally and hierarchically within the principles that govern SUS, with access to health services, from Primary Care to the tertiary level of attention. There have been improvements in the structure of the sector, but epidemiological indicators remain unfavorable and unequal when compared to those of the rest of the Brazilian population, especially with regard to the morbidity and mortality caused by avoidable diseases, such as anemia, malnutrition, and respiratory and infectious diseases ${ }^{(3)}$.

Among the peculiarities of caring for indigenous peoples, there are cultural, social, historical, economic, and political aspects, which interfere in the organization of attention and, consequently, in health practices. With regard to the nursing work process, considering the limited permanent education actions and qualification of workers, the space of assistance becomes a field in which there is struggle, as well as cultural friction between professionals and population, which leads to a dissociation of traditional health practices. If, on one side, the formation by the service tends to diminish this disparity with time, on the other, it is highly affected by the high turnover of professionals in indigenous areas, due to precarious work contracts and to the demobilization of the system as a whole ${ }^{(4)}$.

Considering the challenges to implement a health care that is qualified and in line with the principles and directives prescribed by public health policies, as well as the scarcity of data in literature that explore this theme ${ }^{(5)}$, this study adopted the Theory of Practical Intervention of Nursing in Collective Health (TIPESC) ${ }^{(1)}$ as its theoretical and methodological framework, to answer the guiding question: "How is the work of a nursing team characterized in the territory of an indigenous population, considering the dimensions of management, assistance, teaching and research?"

In this study, the strengths, specificities and limitations of a nursing team in an indigenous health district are highlighted through description and problematization, showing the relevance of its objective and justifying it. The results found can subsidize the planning of actions and the improvement of the work of the nursing and health teams in further studies.

\section{OBJECTIVE}

To discuss the potential and the limits of the actions of the nursing team in the Indigenous Primary Health Care (IPHC).

\section{METHODS}

\section{Ethical aspects}

This study was approved by the Research Ethics Committee of the Universidade Guarulhos and authorized by the Coordination of the Special Yanomami Indigenous Health District (DSEI).

\section{Design, period, and place of study}

Exploratory and quantitative study, guided by the STROBE tool. It addresses the work of the nursing team in the Yanomamim DSEl, whose headquarters are in the city of Boa Vista, capital of the state Roraima, which also attends to the state of Amazonas.

\section{Population; criteria of inclusion and exclusion}

At the beginning of data collection, the Yanomami DSEl counted with a work force of 75 nurses and 310 nursing technicians. To guarantee the reliability of data, the probabilistic sample was calculated for 63 nurses and 172 nursing technicians, considering a $95 \%$ confidence index and a sample error (a) of $5 \%$.

Data collection took place from May to November 2018. 260 nursing professionals were invited, from which 230 accepted participating in the study - 62 nurses and 168 nursing technicians. The others refused participation, which they justified by stating to be uninterested or unavailable for participation. The criteria of inclusion considered included participants who worked in the DSEl for at least three months, as nurses or nursing technicians. No exclusion criterion was used.

\section{Study protocol}

To characterize nursing practices, this study used an instrument adapted from the models used in other studies about the International Classification of Nursing Practices in Collective Health (CIPESC ${ }^{(6-7)}$. The instrument consists in a list of actions developed by the professionals in the nursing team and how frequently they were carried out: daily, weekly, monthly, quarterly, bi-annually, annually, does not perform it, or does not apply. This 
latter frequency classification is related to activities that do not integrate the group of actions assigned to that professional or service, in the context of actions of the Yanomami DSEI. The instruments were made available to the professionals via Google Form ${ }^{\circledR}$, and invitations to participate were sent via email and WhatsApp; in the second stage of collection, the researcher approached the professionals in their work places or through telephone, filling the instrument in with the participant. On one hand, the use of the technology was a facilitator; on the other, many participants were resistant to access the instrument on-line, which meant that the presence of the researcher was required.

\section{Analysis of results and statistics}

The data collected was organized in Microsoft Office Excel ${ }^{\circledR}$ spreadsheets, and the descriptive statistical analysis was carried out using the software Statistical Package for the Social Sciences (SPSS) ${ }^{\circledast}$. A descriptive analysis of data was conducted using the absolute and relative frequencies of the results in the forms adapted from the models used in other studies about the International Classification of Nursing Practices in Collective Health (CIPESC) (6). The frequency with which the activities were carried out in the Yanomami DSEl were evaluated using the instrument, and grouped in a) daily, weekly, and monthly; b) quarterly, bi-annually and annually; and c) was never carried out and does not apply. For each group of activities analyzed, the median was calculated, and was defined as a parameter for the comparison of results.

The TIPESC ${ }^{(1)}$, whose philosophical bases are supported by the concepts of historicity and of the dynamic nature of phenomena in reality, defines collective health care and the work process of assistance in nursing, which were adopted as analytical categories of the study. The first is the conscious intervention in the healthdisease process of individuals and collectivities; the second is the articulated activity between disciplines and fields of knowledge, to organize services and health practices. Furthermore, as it was the theoretical and methodological framework adopted, TIPESC permeates the entire process of production of knowledge presented here, from the theoretical bases of collective health, that illuminate the phenomenon studied, to the operationalization of the capture and interpretation of objective reality, which are the first stages of the theory which lead the contradictions of the phenomenon to emerge and enables its exploration as an object that can receive an intervention. In addition, TIPESC is powerful in the articulation between the reality of the dimensions of phenomena, which, in the present study, are represented by national law in its structural dimensions, the organization of working process in its particular dimension, and by the practices of the professionals in nursing teams in its singular dimension.

\section{RESULTS}

Among the participants of the study, 168 (73\%) were nursing technicians and 62 (27\%) were nurses. The mean age of the entire sample was 36 years (Standard deviation $[S D]=8.4$ ). Regarding the time of formation, the mean was 8.9 years $(S D=5.5)$; the mean time working in the field was 7.4 years $(S D=5.2)$, and the mean time working in the current role was 6.7 years $(S D=4.6)$.
Among the nurses, 30 (48.3\%) finished a lato sensu specialization course. Regarding their marital status, 144 (62.6\%) of professionals were married or lived with partners; $69(30.0 \%)$ were single; 16 (7.0\%) were separated or divorced; and $1(0.4 \%)$ was a widower.

Regarding the activities carried out by nurses and nursing technicians, according to their field of action (assistance, management, teaching, and research), 184 participants (80\%) performed activities in assistance most of the time; 119 (51.7\%) never performed management activities; 180 (78.3\%) never performed teaching activities; and 211 (91.7\%) never carried out research.

Among the nurses and nursing technicians, the greatest difference was in the performance of management activities, carried out by more than half of the nurses most of the time, although $70 \%$ of nursing technicians had never done them. With regard to assistance activities carried out always or most of the time, the percentage varied from $90 \%$ to $80 \%$, for nurses and technicians, respectively (Figure 1).
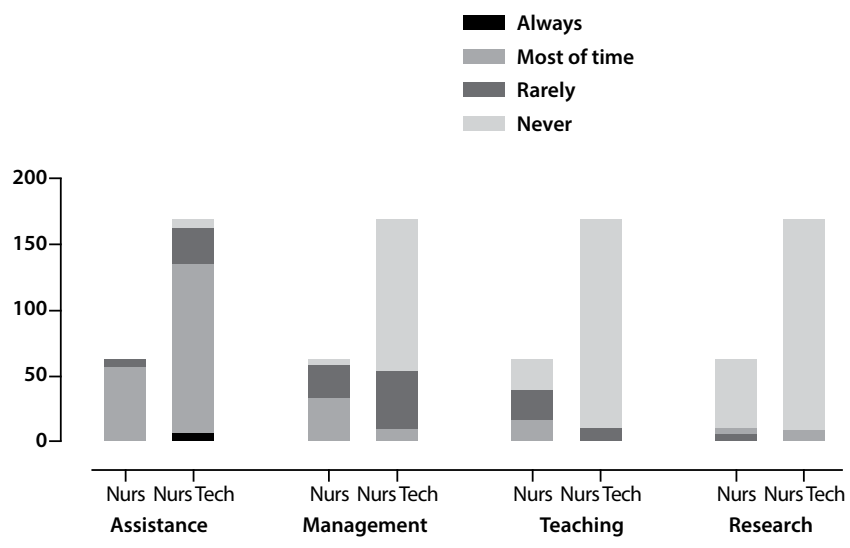

Figure 1 - Distribution of the subjects of the study according to their field of work in nursing $(\mathrm{N}=320)$, Boa Vista, Roraima, Brazil, 2018

Many assistance activities were carried out by the nurses (Figure 2) and nursing technicians (Figure 3), with similar frequencies. Activities above the median had an inverse relation to daily, weekly, and monthly frequencies, while activities above the mean had an inverse relation with the frequencies "does not perform it" and "do not apply".

The mean for assistance activities carried out daily, weekly, or monthly was $79 \%$ for the nurses, and $81.5 \%$ for nursing technicians. In assistance activities, stood out, for both professional categories, embracing, reception, administration of inhalation, endovenous, oral, and intramuscular medications, administration of standard or prescribed medications, urgency and emergency care, urgency materials verification, wound dressing, guidance to pregnant women, children, and women going through the puerperium, and vital sign assessment.

Specifically for nurses, the administration of intradermal (82.3\%), subcutaneous $(85.5 \%)$, and sublingual $(79 \%)$ medications, nursing consultations $(90.3 \%)$, prescription of nursing care $(88.7 \%)$, and written references for other services (85.5\%). They were also carried out by most interviewees and represented by frequencies above the median (Figure 2). For nursing technicians, in addition to activities that were common to nurses, the replacement of urgency materials (88.7\%) also stood out (Figure 3). 


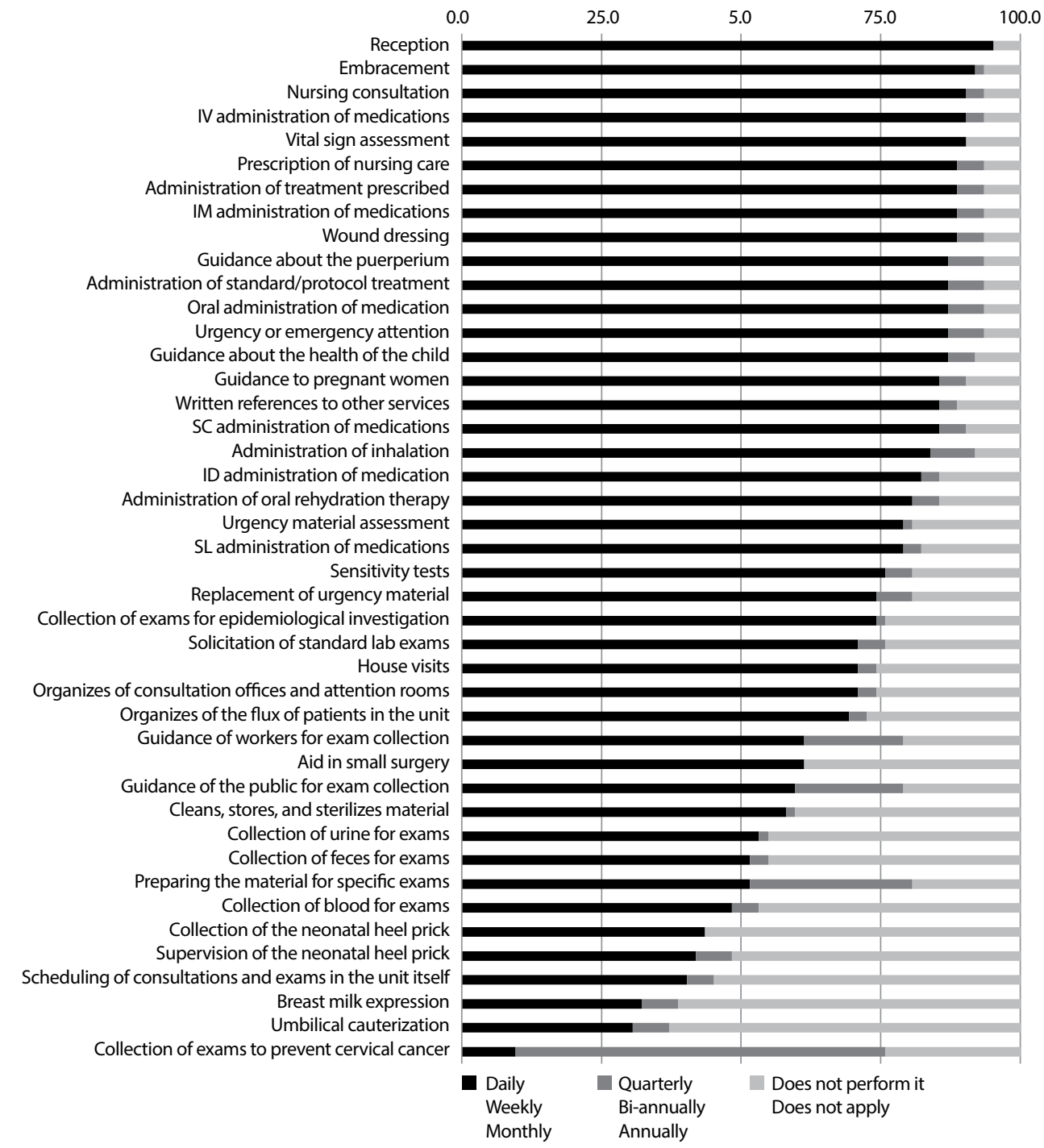

Note: EV - endovenous; IM - intramuscular; SC - subcutaneous; ID - intradermal; SL - sublingual.

Figure 2 - Frequency of assistance activities carried out by the nurses, Boa Vista, 2018

Some activities deserve to be mentioned despite being below the median. House visits were carried out daily, weekly, or monthly by $71 \%$ of nurses and $79.8 \%$ of nursing technicians; the aid in small surgeries took place with a frequency of $61.3 \%$ for both categories, and the collection of materials for exams to prevent against cervical cancer was carried out quarterly, byannually, or annually by $66.1 \%$ of nurses and $63.7 \%$ of nursing technicians. Monthly, quarterly, bi-annual, and annual participation in local, district, or city health meetings was pointed out by more than $72 \%$ of the interviewees, according to how frequent the meetings were.

Other activities also stood out, such as breast milk expression and umbilical cauterization, which were not carried out by more than $62 \%$ of nurses and $72 \%$ of nursing technicians.

Part of the planning activities, despite being mostly a responsibility of nurses (Figure 4), due to their complexity and character, can be carried out by the nursing technicians (Figure 5), under supervision and as an activity shared by the team.
Medians for planning activities carried out daily, weekly, and monthly by nurses and nursing technicians were, respectively, $72.6 \%$ and $58.9 \%$. Both categories frequently (above the median) carry out epidemiological and health surveillance, assessment of vaccination status, identification of health problems, performance of activities with the health team, groups of users and families, provision of communication and transport, elaboration of reports and bulletins for the requisition of supplies.

Still, among the most common actions for nursing technicians, stand out the administration of vaccines, assessment of sterilization, activities with the community and speeches for students, parents, teachers, and the community. The nurses mainly analyze and propose solutions to the health problems, participate and plan the schedules of the health units, plan the activities with teams and users, predict and provide supplies for the sector, and carry out meetings with the health and nursing teams.

Private actions by nurses, such as coordination, planning, and supervision of the services of the nursing and health teams, distribution of tasks, elaboration of scales, provision, prediction, and requisition of supplies and medication, and cleaning supervision, were some of the most carried out activities in this group.

The activities that are carried out the least are Education and Research. In Education, $95.2 \%$ of the nurses and $87.5 \%$ of nursing technicians participated in refreshing courses. Training programs for continued education are planned by $64.5 \%$ or nurses, while $84.5 \%$ of technicians do not participate in this planning.

Nurses worked on the training of human resources with high school in more than $50 \%$ of occasions, although only a little more than $32 \%$ of them stated to have trained other nurses and health professionals. Less than $2 \%$ of interviewees carried out or participated in scientific researches. 


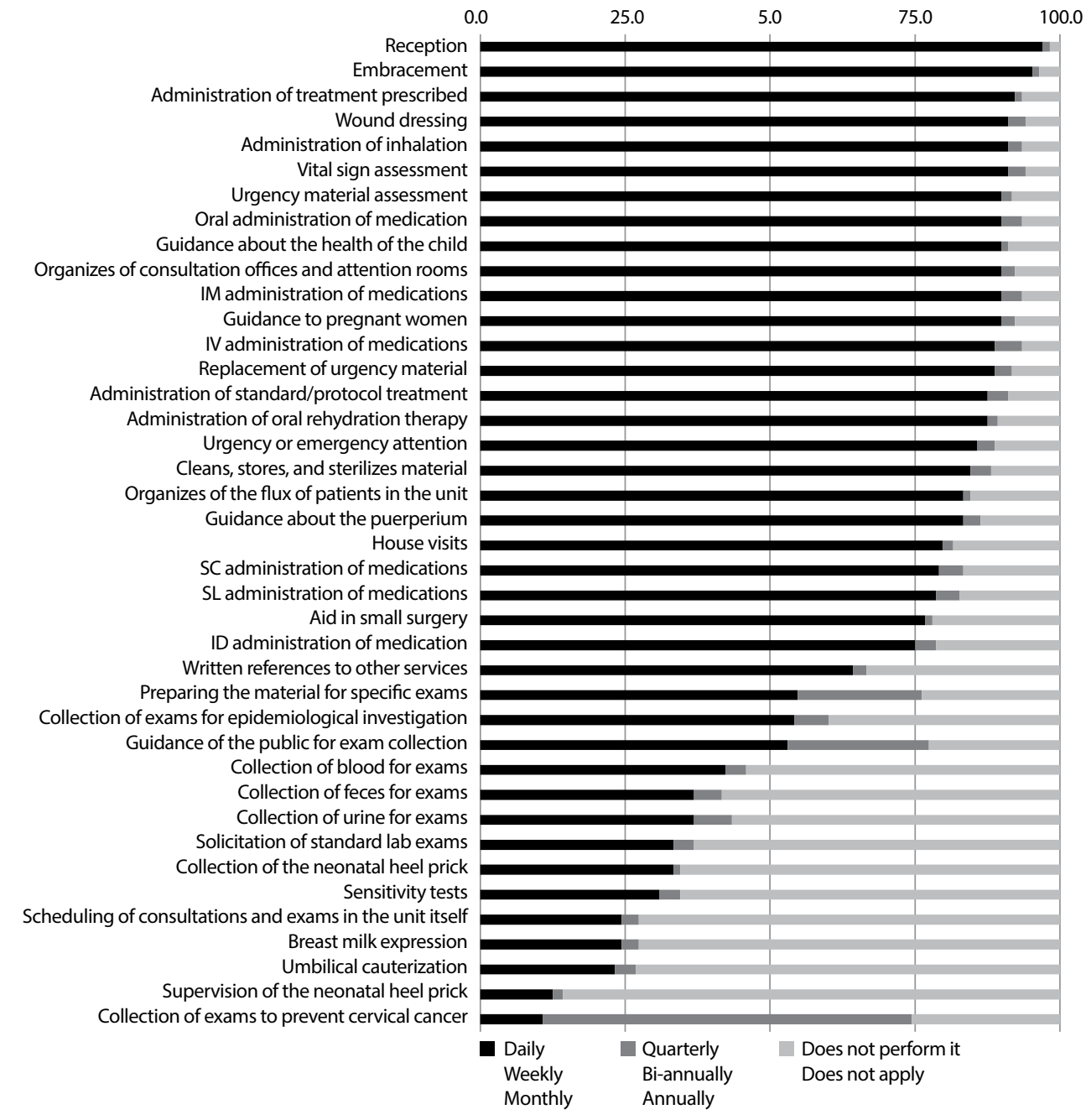

Note: EV - endovenous; IM - intramuscular; SC - subcutaneous; ID - intradermal; SL - sublingual.

Figure 3 - Frequency of assistance activities carried out by nursing technicians, Boa Vista, Roraima, Brazil, 2018

the indigenous population was based on these principles, and the DSY (the Yanomami Health District) was the first district to be established and to develop work methodologies, that were later applied in other DSEIs ${ }^{(8)}$

The attention to the indigenous population in Brazil exemplifies the diversity of health practices. A study carried out about the challenges of Primary Education for indigenous health highlighted that, although the percentage is small, the social diversity and the peculiarities that involve each of the more than 300 ethnic groups that inhabit the Brazilian territory appear as having negative epidemiological indicators, when compared to the rest of the population ${ }^{(3)}$.

In the 2010 census, 817 people declared to be indigenous, corresponding to $0.4 \%$ of the Brazilian population, with a higher concentration in the state of Amazonas ${ }^{(9)}$. The Yanomami represent the largest

\section{DISCUSSION}

Historically, IPHC went through reformulations. Before the 1988 Federal Constitution, the indigenous population was expected to be assimilated by the rest of the population, based on a posture of the State as a tutor. After 1988, this population had its citizenship rights defined and guaranteed, favoring the formulation of other public policies that are specific to these groups and following international recommendations ${ }^{(3)}$.

Even with the advent of SUS, the specificity of the indigenous peoples was not immediately recognized, as prescribed in the principles of Primary Health Care (PHC). Indigenous and nonindigenous social movements discussed the issue widely since the decade of 1980; in 2000, the National Policy of Attention to the Health of Indigenous Peoples (PNAISP) was enacted ${ }^{(2)}$. Among numerous measures, health legislation incorporated elements that required respect to the specificities of each people, including social, cultural, logistic, and epidemiological issues, respecting traditional knowledge popularly practiced and incorporating indigenous workers in the field of health ${ }^{(3)}$. The structure of the attention to semi-isolated ethnic group in the Americas. They are divided in four linguistic subgroups (Yanomae, Yanõmami, Sanima, and Ninam). From the 35 thousand Yanomami Indians, more than 25 thousand are located in Brazil. They survive through activities such as hunting, fishing, and small-scale agriculture ${ }^{(8)}$.

Within the context of health assistance of the indigenous population, nursing has an essential role. In the Yanomami DSEI, it was found that nurses accumulate activities of assistance and management, which are under the responsibility of more than $50 \%$ of interviewees. Among the different facets of nursing actions, one must consider that management and assistance are complementary, despite there being recognized conflicts and tensions in daily work, related to disputes about production and knowledge spaces among the different professionals who make up the health team ${ }^{(10)}$.

The work of the nurse takes place in two dimensions, being targeted both at the assistance of individuals and collectives and to the management of health services and teams. They need to act in many different ways and there must be many possibilities of intervening to transform epidemiological profiles. A tendency 
0.0

25.0

5.0

75.0

100.0

Coordinates and oversees nursing services

Plans nursing services

Identifies health problems

Analyses health problems

Arranges for communication and transport

Carries out activities with the families

Requires supplies

Oversees and controls health personnel

Predicts supply needs

Carries out meetings with nursing personnel Provides supplies

Predicts and provides vaccines

Plans for the scheduling plan of the health unit

Epidemiological surveillance actions

Plans activities with user groups

Predicts medication

Provides medication Analyses supplies

Carries out activities with the community Carries out lectures on disease prevention with the...

Predicts the number of nursing consultations.

Plans activities with the community Plans human resources

Requests human resources

Elaborates routines to control environmental... Vaccine administration

Carries out meetings with Community Health Agents Arranges for repairs and maintenance of equipment.

Analyses permanent supplies

Oversees electric and hydraulic networks Formally evaluates Community Health Agents Participates in meetings of the Municipal Health. Participates in meetings of the District Health Council Carries out purchases

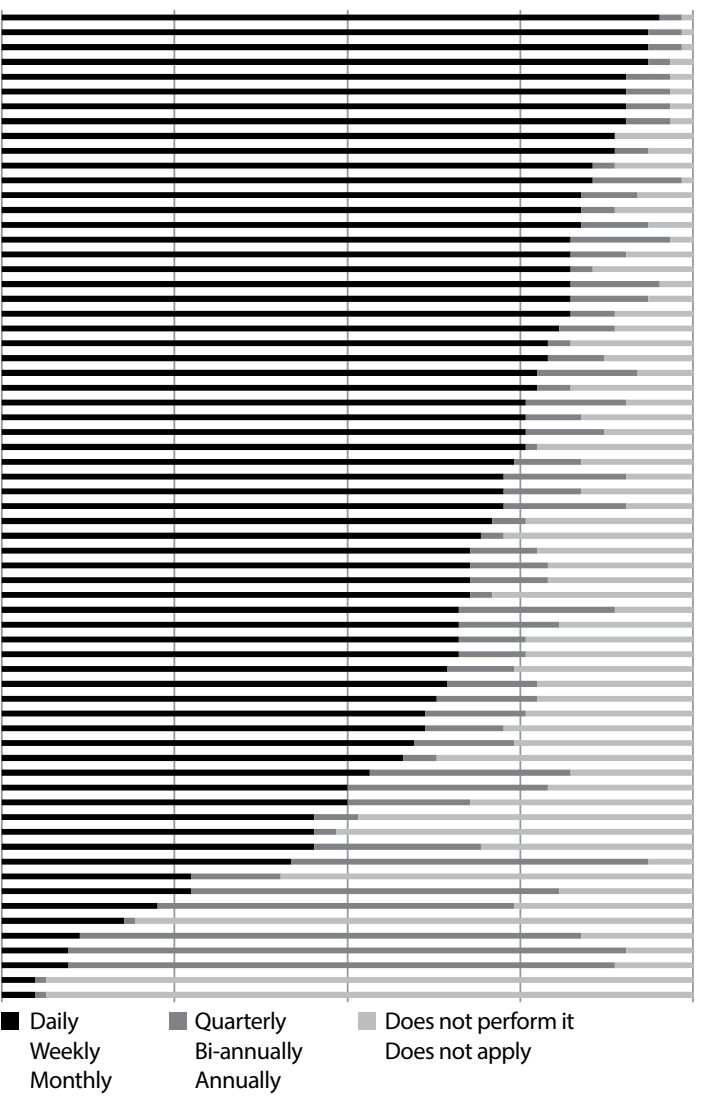

Figure 4 - Frequency of planning activities carried out by nurses, Boa Vista, Roraima, Brazil, 2018

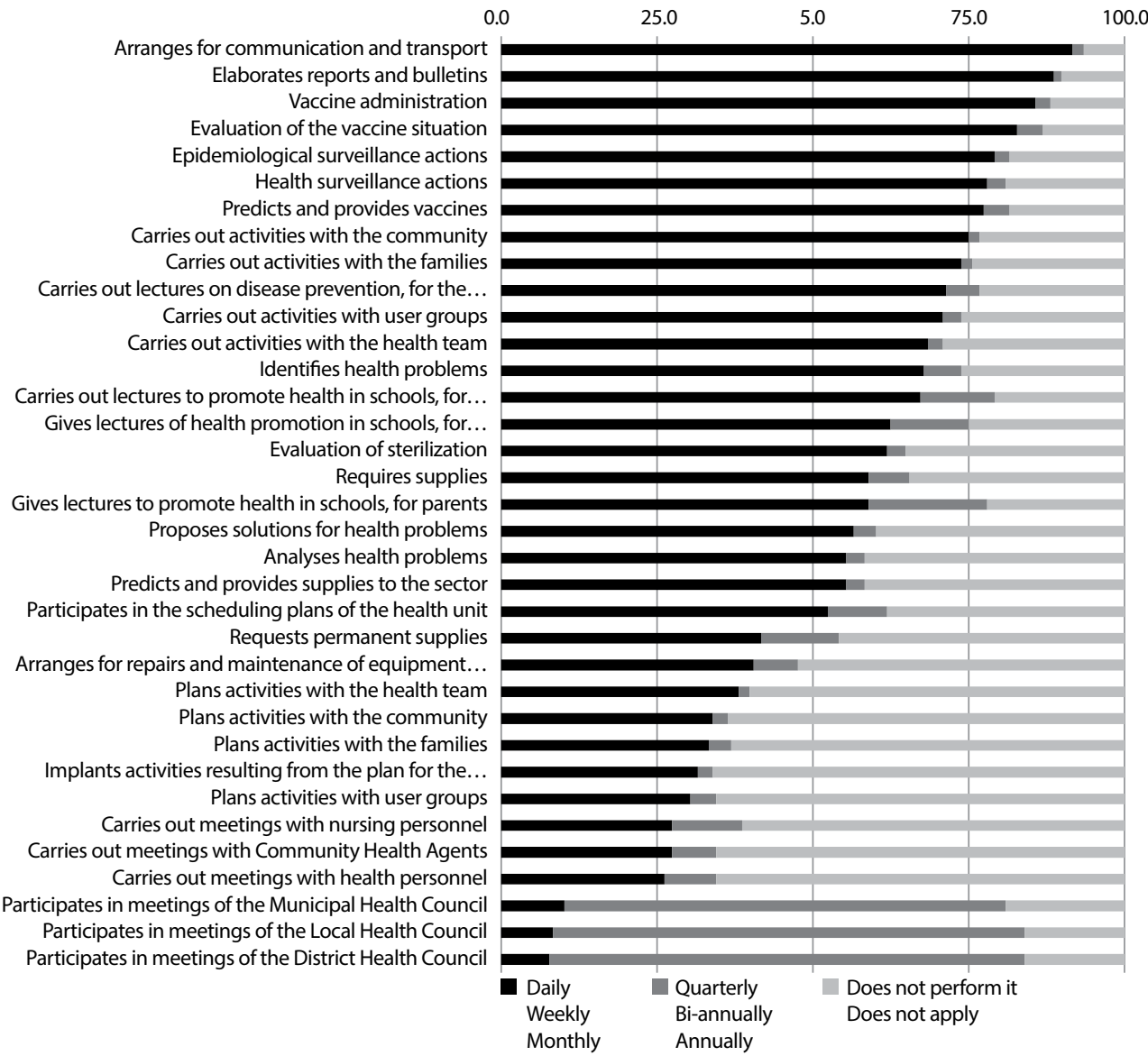

Figure 5 - Frequency of planning activities carried out by nursing technicians, Boa Vista, Roraima, Brazil, 2018 for nurses to carry out less assistance activities has been noticed, especially regarding nursing consultations ${ }^{(11)}$. This study, as opposed to literature ${ }^{(11)}$, found that the nurses have participated in both management and assistance. This aspect is a strength with regard to the assistance to indigenous peoples, presenting the possibility of planning actions in line with the needs found at the moment of assistance. The accumulation of activities, however, may lead to overload, in circumstances where personnel is undersized.

Problems that affect the SUS are reflected and repeated in indigenous health. Among them, there is the questionable efficiency of professional practices to modify epidemiological profiles and the life and health conditions of the population. The conditions for the attention to the indigenous population are adverse and unique. There are failures in the attempt to offer a unique type of attention that derive from difficulties with the language and the lack of consideration of cultural needs. The nurse must promote a broader access to the service through a strategy that can improve a deficient communication, which creates a barrier to the access of indigenous peoples to health services, compromising assistance $^{(12)}$.

As an example of the cultural needs that determine care, the Sanumá, a subgroup of the Yanomami linguistic family, 
consider that allopathic medications and biomedical treatments act on unpleasant symptoms and sensations, that could be soften or cured by traditional actions, but not necessarily through the actions of the shamans. However, surgical interventions are not always seen as positive, since the aggression caused by the incision may introduce harmful elements in the indigenous blood, generating further illness that demands the action of the shaman to be cured. The biomedical and traditional systems are assumed to be complementary, and there must be freedom of choice ${ }^{(13)}$.

The application of biomedical interventions is related to the intersubjectivity between the professional and indigenous person, the first being supported by scientific and hegemonic knowledge, while the other is so by traditions and customs. The imposition of interventions can lead to conflict, wearing, and to the loss of a bond to the community. Only an assistance based on the respect and on the knowledge about an ethnic group will be able to aid and combine knowledge, transforming the epidemiological profile and improving the health conditions of the population. An example of the interference of the cultural aspect in assistance is the low frequency of the realization of breast milk expression and umbilical cauterization, practices that indigenous mothers refuse doing, since they have available to them traditional resources that can deal with these needs.

The application of the specific knowledge of the nurse for $\mathrm{PHC}$ situations was found to be relevant considering the results found. The social and historically determined character of the profession predicts that the other members of the team will be articulated in a broad production of health, which is no longer focused on clinic and cure, but is prevalent in care as a whole, in different social spaces and vital cycles. The development of competences to act in this setting should be supported by activities of permanent education for the professionals ${ }^{(11)}$.

Still with regard to the formation to act in indigenous health, the study analyzed the teaching of a discipline related to indigenous health in graduation courses of nursing in the 69 public and private higher education institutions in the North of Brazil. The formation has not been valuing traditional practices, reinforcing a paradox between the courses offered in the region and the formation that should be targeted at local reality. The approach to indigenous care was peripheral to the learning process, and did not occupy a central position, as policies of health education and formation prescribe ${ }^{(14)}$. In indigenous health, the qualification of professionals to act in a specific cultural context determines the quality of assistance. The results found here showed that there is space for practices of continued education and professional qualification to increase.

The nurses recognized embracement, nursing consultation, and house visits as frequent activities in indigenous care. In the daily practice of health services, these practices have been found to follow a hegemonic model of clinical exercise, to the detriment of a clinic of care, that is, to a clinic that is a space for the listening of the needs with a broader look on the individual, the family, and the community. The proposition for a clinic of care faces operational and organizational obstacles, such as the lack of support from protocols, of appropriated physical spaces, and of technical support. The hegemonic clinical practice, based on the biomedical model of attention, generates conflicts and tensions in the actions of nurses, confronted with the undefinition of the limits of their activities. On the other hand, in the clinic of care, it is possible to offer an integral and broad care ${ }^{(15)}$.

Therefore, and under the light of the process of work in health, results have shown that the organization of work in the DSY corresponds to a public policy that faces advances and regressions in its structure and operationalization. There is a diversity of activities carried out by the nursing team that is a strength in the assistance of the indigenous population.

If the object of the working process in indigenous health was an assistance that is integral, wide, and cultural, the objective of the assistance should be becoming anchored on the search for quality of life, the guarantee of health, and on the full exercise of citizenship and tradition. The production of health is merged with the very production of the conditions of life of the indigenous people, which, through centuries, suffered with either the invasion of their cultures or the disregard of the public powers towards their existence. It is essential to balance the biomedical knowledge to deal with adverse life conditions, while, simultaneously, respecting tradition, culture, and beliefs.

This is where the instruments that are necessary to the process of work in health come in. Resources used in the assistance of SUS are insufficient and impotent with regard to indigenous needs. An attentive analysis of the object and of the objective of the process of work is sufficient to show that the imposition of health practices based on the hegemonic model, even when enveloped in a cultural disguise, is not enough. The participation in the planning of care, the maintenance of a bond, the capture and satisfaction of needs from the point of view of the population, and the strengthening of nursing actions are important means to transform this object.

\section{Study limitations}

As a limitation of this study, its quantitative approach stands out, which was used to measure the practice of nursing from the lens of the hegemonic model. The application of an instrument may not be enough to explain the complexity of nursing work, but it allows for an important discussion about what the nurse and the nursing technician carry out in this space. Further studies are necessary for an in-depth look at the quality of assistance, with regard to the peculiarities of actions and the potentialities of attention in the necessary cultural care.

\section{Contributions to the Field of Nursing}

The results presented are expected to enable the development of tools to provide instruments for the formation, qualification, and nursing work process in the Yanomami DSEl and in other DSEls. There nursing team is a strength in the management of the care of indigenous populations, but education and research were found to be limits in the nursing work. Therefore, the results of this study allow for a reflection on the importance of investments in the formation of the nurse, focused on actions regarding indigenous health and peculiarities of each territory, as well as the development of researches with this population, especially in the higher education institutions in the North of the country. 


\section{FINAL CONSIDERATIONS}

This study identified the strengths and limits in the actions of the nursing team in the IPHC. The activities carried out for the assistance of the indigenous peoples are organized based on the PNASPI directives, which regulate them. In this context, nursing assistance is essential for the modification and monitoring of epidemiological profiles in the indigenous population.

The results made it possible to find what are the actions of the nursing team in the Yanomami DSEl, and how often they are carried out. As a strength, the involvement of nurses in the assistance stands out, as it enables a direct intervention in the potential for wear and reinforcement that were found in the population; also, nursing consultations, house visits, and epidemiological surveillance showed that actions of the nurses in the monitoring of the conditions of life and health in the territory. Another result that stood out is the participation of professionals in local and regional health conferences, spaces of deliberation, debate, and for the strengthening of SUS.

However, some limitations can be pointed out. If, on one hand, the assistance is highly involved in the management, there is, on the other hand, a constant need for the qualification of the professionals, indicated by literature. This is opposed to the result that indicates the nearly nonexistent participation of nurses in the dimensions of education and research. Another aggravating factor is the small insertion of traditional care as a discipline in graduation nursing courses in the institutions in the North of the country. It stands out that the professional formation and qualification cannot be limited by the technical aspects of the practices and must find support on their ethnic-cultural character, to respect and preserve the indigenous peoples' right to health and life.

The activities carried out in the Yanomami DSEI seek to articulate knowledge and instruments targeted at the attention to the needs of the population. There is room for the growth and development of health care, as well as for the professionals who work in this territory. As long as investments, public policies, and health rights are preserved, the strengths of nursing care can be reinforced, and the conditions of life and health in the communities can be improved.

\section{FUNDING}

Coordination for the Improvement of Higher Education Personnel (CAPES) for supporting the Postgraduate Program in Nursing with the granting of scholarships and school fees for Master and Doctorate.

\section{REFERENCES}

1. Egry EY. Saúde Coletiva: um novo método em enfermagem. São Paulo; Ícone; 1996.

2. Ministério da Saúde (BR). Fundação Nacional de Saúde. Política Nacional de Atenção à Saúde dos Povos Indígenas. 2a ed. Brasília: Ministério da Saúde. Fundação Nacional de Saúde; 2002. 40 p.

3. Mendes AM, Leite MS, Langdon EJ, Grisotti M. O desafio da atenção primária na saúde indígena no Brasil. Rev Panam Salud Pública. 2018;42:e184. https://doi.org/10.26633/RPSP.2018.184

4. Ribeiro AA, Aciole GG, Arantes CIS, Reading J, Kurtz DLM, Rossi LA. The work process and care production in a Brazilian indigenous health service. Esc Anna Nery. 2017;21(4):e20170029. https://doi.org/10.1590/2177-9465-ean-2017-0029

5. Sandes LFF, Freitas DA, Souza MFNS, Leite KBS. Atenção primária à saúde de indígenas sul-americanos: revisão integrativa da literatura. Rev Panam Salud Pública. 2018;42:e163. https://doi.org/10.26633/RPSP.2018.163

6. Cubas MR, Egry EY, Altino DM, Duarte FO, Pereira KCM, Apostolico MR. Adaptação dos instrumentos de coleta de dados do projeto CIPESC à realidade Curitibana. In: Egry EY, Cubas MR (Org) O trabalho da Enfermagem em saúde coletiva no Cenário CIPESC: guia para pesquisadores. Curitiba: Associação Brasileira de Enfermagem; 2006.

7. Antunes MJM, Silva IA, Egry EY, Sena RR, Almeida MCP. Projeto de classificação das práticas de enfermagem em saúde coletiva no Brasil: manual do pesquisador. Parte I: orientações para o trabalho de campo. Brasília: Associação Brasileira de Enfermagem; 1997 (Série Didática: Enfermagem no SUS).

8. Ministério da Saúde (BR). Fundação Nacional de Saúde. Coordenação Regional de Roraima. Situação de Saúde e Assistência: relatório epidemiológico operacional, novembro de 2009 a março de 2010 [Internet]. 2010 [cited 2019 Jun 13]. Available from: https://hutukara.org/ images/stories/pdf/03_situacao_saude_yanomami2010.pdf

9. Instituto Brasileiro de Geografia e Estatística-IBGE, Os indígenas no censo demográfico 2010: primeiras considerações com base no quesito cor ou raça [Internet]. 2010 [cited 2019 Jun 13]. Avaiable from: http://www.ibge.gov.br/indigenas/indigena_censo2010.pdf

10. Galavote HS, Zandonade E, Garcia ACP, Freitas PSS, Seidl H, Contarato PC, Andrade MAC, Lima RCD. The nurse's work in primary health care. Esc Anna Nery. 2016;20(1):90-8. https://doi.org/10.5935/1414-8145.20160013

11. Ferreira SRS, Périco LAD, Dias VRGF. The complexity of the work of nurses in Primary Health Care. Rev Bras Enferm. 2018;71(Supl 1):704-9. https://doi.org/10.1590/0034-7167-2017-0471

12. Borghi AC, Alvarez AM, Marcon SS, Carreira L. Cultural singularities: indigenous elderly access to Public Health Service. Rev Esc Enferm USP. 2015;49(4):589-95. https://doi.org/10.1590/S0080-623420150000400008

13. Guimarães SMF. O sistema médico Sanumá-Yanomami e sua interação com as práticas biomédicas de atenção à saúde. Cad Saúde Pública. 2015;31(10). https://doi.org/10.1590/0102-311X00194414 
14. Castro NJC, Cavalcante IMS, Palheta ASE, Santos DN. Inclusion of undergraduate nursing subjects about traditional populations from the amazon region. Cogitare Enferm. 2017;(22)2:e49730. https://doi.org/10.5380/ce.v22i2.49730

15. Matumoto S, Fortuna CM, Kawata LS, Mishima SM, Pereira MJB. Nurses' clinical practice in primary care: a process under construction. Rev Latino-Am Enferm. 2011;19(1):123-30. https://doi.org/10.1590/S0104-11692011000100017 